\title{
POSTHARVEST NITROUS OXIDE EMISSIONS FROM A SUBTROPICAL OXISOL AS INFLUENCED BY SUMMER CROP RESIDUES AND THEIR MANAGEMENT ${ }^{(1)}$
}

\author{
Luisa Fernanda Escobar ${ }^{(2)}$, Telmo Jorge Carneiro Amado ${ }^{(3)}$, Cimélio \\ Bayer $^{(4)}$, Luis Fernando Chavez ${ }^{(2)}$, Josiléia Acordi Zanatta ${ }^{(2)} \&$ \\ Jackson Ernani Fiorin ${ }^{(5)}$
}

\begin{abstract}
SUMMARY
Nitrous oxide $\left(\mathrm{N}_{2} \mathrm{O}\right)$ is the most important non- $\mathrm{CO}_{2}$ greenhouse gas and soil management systems should be evaluated for their $\mathrm{N}_{2} \mathrm{O}$ mitigation potential. This research evaluated a long-term (22 years) experiment testing the effect of soil management systems on $\mathrm{N}_{2} \mathrm{O}$ emissions in the postharvest period (autumn) from a subtropical Rhodic Hapludox at the research center FUNDACEP, in Cruz Alta, state of Rio Grande do Sul. Three treatments were evaluated, one under conventional tillage with soybean residues (CTsoybean) and two under no-tillage with soybean (NTsoybean) and maize residues (NTmaize). $\mathrm{N}_{2} \mathrm{O}$ emissions were measured eight times within 24 days (May 2007) using closed static chambers. Gas flows were obtained based on the relations between gas concentrations in the chamber at regular intervals $(0,15,30,45 \mathrm{~min})$ analyzed by gas chromatography. After soybean harvest, accumulated $\mathrm{N}_{2} \mathrm{O}$ emissions in the period were approximately three times higher in the untilled soil $\left(164 \mathrm{mg} \mathrm{m}^{-2} \mathrm{~N}\right)$ than under $\mathrm{CT}$ $\left(51 \mathrm{mg} \mathrm{m}^{-2} \mathrm{~N}\right)$, with a short-lived $\mathrm{N}_{2} \mathrm{O}$ peak of $670 \mathrm{mg} \mathrm{m}^{-2} \mathrm{~h}^{-1} \mathrm{~N}$. In contrast, soil $\mathrm{N}_{2} \mathrm{O}$ emissions in NT were lower after maize than after soybean, with a $\mathrm{N}_{2} \mathrm{O}$ peak of $127 \mathrm{~g} \mathrm{~m}^{-2} \mathrm{~h}^{-1} \mathrm{~N}$. The multivariate analysis of $\mathrm{N}_{2} \mathrm{O}$ fluxes and soil variables, which were determined simultaneously with air sampling, demonstrated that the main
\end{abstract}

\footnotetext{
(1) Parte da Pesquisa de Mestrado da primeira autora junto ao Programa de Pós-Graduação em Ciência do Solo (PPGCS) da Universidade Federal de Santa Maria - UFSM. Recebido para publicação em julho de 2008 e aprovado em novembro de 2009.

(2) Doutorando do PPG Ciência do Solo, Universidade Federal do Rio Grande do Sul - UFRGS. Av. Bento Gonçalves 7712, CEP 91501-970 Porto Alegre (RS).E-mails: luisaesc@yahoo.com; leluchavez@yahoo.com; josizanatta@yahoo.com

(3) Professor do Departamento de Solos, Universidade Federal de Santa Maria - UFSM. Av. Roraima 1000, Camobi, CEP 97105900 Santa Maria (RS). Bolsista do CNPq. E-mail: tamado@smail.ufsm.br

(4) Professor do Departamento de Solos, UFRGS. Bolsista do CNPq. E-mail: cimelio.bayer@ufrgs.br

(5) Pesquisador da FUNDACEP. Rod. RS 342, km 149, CEP 98100-970 Cruz Alta (RS). E-mail: jackson@fundacep.com.br
} 
driving variables of soil $\mathrm{N}_{2} \mathrm{O}$ emissions were soil microbial activity, temperature, water-filled pore space, and $\mathrm{NO}_{3}{ }^{-}$content. To replace soybean monoculture, crop rotation including maize must be considered as a strategy to decrease soil $\mathrm{N}_{2} \mathrm{O}$ emissions from NT soils in Southern Brazil in a Autumn.

Index terms: global warming, subtropical soils, greenhouse gases, soil tillage, crop rotation.

\title{
RESUMO: EMISSÃO DE ÓXIDO NITROSO DO SOLO NO PERIODO PÓS- COLHEITA ALTERADA PELOS RESÍDUOS DAS CULTURAS DE VERÃO E SEU MANEJO EM LATOSSOLO DO SUL DO BRASIL
}

\begin{abstract}
$\mathrm{O}$ óxido nitroso $\left(\mathrm{N}_{2} \mathrm{O}\right)$ é o mais importante gás de efeito estufa excetuando o $\mathrm{CO}_{2}$, e os sistemas de manejo devem ser avaliados quanto ao potencial de mitigação da emissão desse gás. O presente estudo foi realizado em experimento de longa duração (22 anos) e teve como objetivo avaliar o efeito de sistemas de manejo nas emissões de $\mathrm{N}_{2} \mathrm{O}$ no período pós-colheita (outono) em um Latossolo Vermelho distrófico típico situado na Fundação Centro de Experimentação e Pesquisa Fecotrigo (FUNDACEP), Cruz Alta, RS. Três sistemas de manejo foram avaliados: um em preparo convencional com residuos de soja (PCsoja) e dois outros em plantio direto com resíduos de soja (PDsoja) e de milho (PDmilho). As emissões de $\mathrm{N}_{2} \mathrm{O}$ foram medidas em oito coletas de amostras de ar no período de 24 dias (maio de 2007), usando o método da câmara estática. Os fluxos foram obtidos pela relação entre as concentrações de gases dentro da câmara em intervalos regulares (0, 15, 30 e $45 \mathrm{~min})$, analisada por cromatografia gasosa. Sobre os resíduos de soja, as emissões de $\mathrm{N}_{2} \mathrm{O}$ no período avaliado foram aproximadamente três vezes superiores no solo em $P D\left(164 \mathrm{mg} \mathrm{m}^{-2}\right.$ de $\left.\mathrm{N}\right)$ do que em PC (51 $\mathrm{mg} \mathrm{m}^{-2}$ de N), atingindo pico máximo de curta duração de emissão de $670 \mathrm{mg} \mathrm{m}^{-2} \mathrm{~h}^{-1}$ de $\mathrm{N}$. Por outro lado, sobre os resíduos de milho, o solo em PD apresentou uma emissão inferior (34 $\mathrm{mg} \mathrm{m}^{-2}$ de N) do que após soja, atingindo valor máximo de $127 \mathrm{mg} \mathrm{m}^{-2} \mathrm{~h}^{-1}$ de $\mathrm{N}$. Variáveis de solo foram avaliadas simultaneamente às coletas de gases, e a análise multivariada dos resultados indicou que as principais variáveis controladoras da emissão de $\mathrm{N}_{2} \mathrm{O}$ foram a atividade microbiana, a temperatura, a porosidade preenchida por água e o teor de $\mathrm{NO}_{3}{ }^{-}$no solo. A inclusão do milho na rotação de culturas deve ser adotada em substituição à monocultura de soja como estratégia de redução da emissão outonal de $\mathrm{N}_{2} \mathrm{O}$ em solos sob plantio direto do Sul do Brasil.
\end{abstract}

Termos de indexação: aquecimento global, solos tropicais, gases de efeito estufa, preparos de solo, rotação de culturas.

\section{INTRODUCTION}

The atmospheric concentrations of the three main greenhouse gases (GHGs) - carbon dioxide $\left(\mathrm{CO}_{2}\right)$, nitrous oxide $\left(\mathrm{N}_{2} \mathrm{O}\right)$, and methane $\left(\mathrm{CH}_{4}\right)$ - have increased rapidly in the last few decades, which is a phenomenon associated to anthropogenic activities (Mosier et al., 1991; 1998). Worldwide, it is estimated that agriculture contributes with approximately $22 \%$ to the total $\mathrm{CO}_{2}$ emissions, $80 \%$ to the total $\mathrm{N}_{2} \mathrm{O}$ and $55 \%$ to the total $\mathrm{CH}_{4}$ emissions (IPCC, 2007). On the other hand, it is estimated that $75 \%$ of $\mathrm{CO}_{2}, 94 \%$ of $\mathrm{N}_{2} \mathrm{O}$, and $91 \%$ of the $\mathrm{CH}_{4}$ emissions in Brazil come from agricultural activities (Embrapa, 2006). Although emitted in smaller amounts, the global warming potential of $\mathrm{N}_{2} \mathrm{O}$ is 296 times higher than of $\mathrm{CO}_{2}$ (IPCC, 2007). Thus, the marked contribution of $\mathrm{N}_{2} \mathrm{O}$ emission by agriculture and the potential of this gas to trap thermal infrared radiation justify the need of characterization of the soil management practices with a way to reduce soil $\mathrm{N}_{2} \mathrm{O}$ emission (Six et al., 2004).

Most $\mathrm{N}_{2} \mathrm{O}$ is produced by nitrification and denitrification processes in the soil (Firestone \& Davidson, 1989). Nitrification, which requires aerobic conditions, depends on $\mathrm{NH}_{4}{ }^{+}$supply and is mediated by autotrophic bacteria, whereas denitrification is performed by anaerobic heterotrophic bacteria, which depend on the availability of labile organic $\mathrm{C}$ (Rice et al., 1988) and $\mathrm{NO}_{3}{ }^{-}$. Their activity is intensified in anaerobic environments or soil microsites with low $\mathrm{O}_{2}$ availability (Moreira \& Siqueira, 2006; Aita \& Giacomini, 2007). In addition to these soil variables, temperature, water-filled pore space (WFPS), and $\mathrm{pH}$ have also been identified as $\mathrm{N}_{2} \mathrm{O}$-production-controlling variables in agricultural soils, since they affect the activity of nitrifying and denitrifying bacteria as well (Maag \& Vinther, 1996; Weitz et al., 2001; Dalal et al., 2003). 
Among the agricultural practices, $\mathrm{N}$ fertilizers, soil tillage, and legume grain crops have been cited regarding their effect on soil $\mathrm{N}_{2} \mathrm{O}$ emissions. The inefficient use of $\mathrm{N}$ fertilizers and continuous legume cropping are mainly responsible for stimulating soil $\mathrm{N}_{2} \mathrm{O}$ emissions to the atmosphere since they increase the soil mineral $\mathrm{N}$ content and influence the soil labile C supply (Dalal et al., 2003; Gomes et al., 2009). In turn, soil tillage affects the majority of the $\mathrm{N}_{2} \mathrm{O}$ emission-controlling soil variables and higher emissions of this GHG have usually been reported in soils under NT than under CT (Rice \& Smith, 1982; Liu et al., 2007). This finding has been attributed to a lower $\mathrm{O}_{2}$ diffusion due to soil compaction (Vinten et al., 2002; Baggs et al., 2003; Liu et al., 2006), mainly in periods of frequent and intense rainfall (Jantalia et al., 2006), and to a higher microbial biomass activity, consuming $\mathrm{O}_{2}$ and forming anaerobic microsites (Baggs et al., 2006). However, most results regarding $\mathrm{N}_{2} \mathrm{O}$ emission were obtained in temperate soils, and limited information is available for tropical and subtropical Oxisols, where favorable soil physical properties of soil structure and aeration as well as rapid water-infiltration may restrict $\mathrm{N}_{2} \mathrm{O}$ production and emission by denitrification (Jantalia et al., 2006; Metay et al., 2007; Jantalia et al., 2008).

The main objective of this study was to evaluate the long-term effect of soil management systems on $\mathrm{N}_{2} \mathrm{O}$ emissions from a Rhodic Hapludox in the postharvest period of summer grain crops (soybean and maize) under the subtropical climatic conditions of the state of Rio Grande do Sul, Brazil.

\section{MATERIAL AND METHODS}

\section{Experimental site characterization}

The study was carried out in a 22-year experiment conducted at the Fundação Centro de Experimentação e Pesquisa Fecotrigo (FUNDACEP), Cruz Alta, state of Rio Grande do Sul (RS), Brazil. The research center FUNDACEP (latitude $28^{\circ} 36^{\prime}$ S, longitude $53^{\circ} 40^{\prime} \mathrm{W}, 409 \mathrm{~m}$ asl) lies in the center of the plateau of the state (Rio Grande do Sul, 1994). The soil is classified as typic dystrophic Red Latosol by the Brazilian Soil Taxonomy System (Embrapa, 2005), and as Rhodic Hapludox by the USDA Soil Taxonomy (USDA, 1999). The regional climate is humid, type Cfa 2a, according to Köppen's classification (Moreno, 1961), with a mean annual rainfall of $1,755 \mathrm{~mm}$ (mean from 1974 to 2006 - FUNDACEP weather station) with an annual drainage volume of $513 \mathrm{~mm}$ and evenly distributed rainfall during the year, slightly concentrated in the spring (Maluf, 2000). The annual mean temperature is $18.7^{\circ} \mathrm{C}$ (mean from 1998 to 2006 - FUNDACEP weather station), with a minimum temperature of $8.6^{\circ} \mathrm{C}$ in July and maximum of $30^{\circ} \mathrm{C}$ in January (Moreno, 1961).
The experiment tested two tillage systems (CT: conventional tillage with plowing + disking operations and NT: no-till with minimum soil disturbance) in the main plots and three crop rotations in sub-plots (13.3 x 30.0 m): CR-0 - wheat (Triticum aestivum L.)/ soybean (Glycine max L. Merr.); CR-1 - wheat/soybean/ black oat (Avena strigosa Schreber)/soybean/black oat+common vetch (Vicia sativa L. Walp)/maize (Zea mays L.)/radish oil (Raphanus sativus var. oleiformis); CR-2 - black oat/soybean/wheat/soybean. Crop rotation 1 was tripled and wheat, black oat and black oat+common vetch were used as initial crops in a way that both soybean and maize were planted in the same summer of every year. At the beginning of the experiment, the soil properties $(0-0.20 \mathrm{~m})$ were the following: $570 \mathrm{~g} \mathrm{~kg}^{-1}$ clay, $120 \mathrm{~g} \mathrm{~kg}^{-1}$ silt, $310 \mathrm{~g} \mathrm{~kg}^{-1}$ sand, $32 \mathrm{~g} \mathrm{~kg}^{-1}$ organic matter, $\mathrm{pH} \mathrm{H} \mathrm{H}_{2} \mathrm{O}=4.5, \mathrm{P}=19 \mathrm{mg} \mathrm{dm}^{-3}$, $\mathrm{K}=0.21 \mathrm{cmol}_{\mathrm{c}} \mathrm{dm}^{-3}, \mathrm{Al}^{3+}=0.12 \mathrm{cmol}_{\mathrm{c}} \mathrm{dm}^{-3}$, and $\mathrm{Ca}^{2+}+\mathrm{Mg}^{2+}=0.42 \mathrm{cmol}_{\mathrm{c}} \mathrm{dm}^{-3}$. The crops were managed according to technical recommendations regarding seeds, fertilization rates, sowing period, pest and disease control, as specifically reported by Campos (2006).

\section{Treatments}

Soil $\mathrm{N}_{2} \mathrm{O}$ emissions were evaluated in CR-1, in May 2007 in three plots in this crop rotation system. Two were assessed after soybean harvest, in succession to black oat, under NT and CT, and the third after maize harvest, in succession to black oat + common vetch, under NT. Maize was harvested on February 28, 2007 , and radish oil was planted immediately after the harvest, while soybean was harvested on April 18,2007 . The cover crop used after soybean harvest was black oat + common vetch, sown with a seed drill SHM 1517. Conventional tillage (CT) consisted of plowing to a depth of $0.20 \mathrm{~m}$, followed by harrow disking to a depth of $0.15 \mathrm{~m}$, within an interval of two days between plowing and harrow disking. In the NT System, the winter cover crop was sown on the maize and soybean residues and soil tilling was restricted to the crop rows. In each treatment, an area of $2 \times 2$ m was delimited for soil $\mathrm{N}_{2} \mathrm{O}$ emission and soil sampling.

\section{Measurements of nitrous oxide emissions}

Soil $\mathrm{N}_{2} \mathrm{O}$ emissions were evaluated eight times in 24 days with sampling intervals ranging from 1 to 5 days, immediately after soil tillage. Air samples for $\mathrm{N}_{2} \mathrm{O}$ analysis were taken using polyvinyl chloride (PVC) static chambers (height $0.20 \mathrm{~m}$, diameter $0.25 \mathrm{~m}$ ). Immediately before air sampling, the atmosphere inside the chamber was homogenized with an internal fan for $30 \mathrm{~s}$ and the internal temperature monitored with a digital thermometer. The chambers were placed on an aluminum base which was inserted $0.05 \mathrm{~m}$ deep into the soil and maintained in the experimental plot during the entire evaluation period. During sampling, the internal chamber atmosphere 
was isolated by filling water into a channel at the upper part of the base upon which the PVC chamber was supported. Three static chambers were used per treatment.

The air was sampled from 10 to 11 a.m., as proposed by Jantalia et al. (2008), 0, 15, 30, and $45 \mathrm{~min}$ after the closure of the chambers, using $20 \mathrm{~mL}$ polypropylene syringes equipped with valves in the top of the chambers. Air samples were cool-stored and taken to the Environmental Biogeochemical Laboratory of the Federal University of Rio Grande do Sul- Porto Alegre - RS, Brazil, where they were analyzed by gas chromatography within less than 24 hours after sampling. $\mathrm{N}_{2} \mathrm{O}$ was determined using a gas chromatograph Shimadzu GC 2014 Greenhouse model, equipped with an electron capture detector (ECD), and a Porapack Q column at $70^{\circ} \mathrm{C}$, using $\mathrm{N}_{2}$ as the carrier gas at a flow of $26 \mathrm{~mL} \mathrm{~min}^{-1}$, injector temperature of $250^{\circ} \mathrm{C}$ and detector temperature of $325^{\circ} \mathrm{C} . \mathrm{N}_{2} \mathrm{O}$ flows were calculated by the equation $F\left(\mathrm{~N}-\mathrm{N}_{2} \mathrm{O}\right)=\mathrm{d}\left[\mathrm{N}_{2} \mathrm{O}\right] / \mathrm{dt} \times 28 \times \mathrm{MW} \times \mathrm{P} \times \mathrm{V} / \mathrm{R} \times \mathrm{T}$, where $\mathrm{d}\left[\mathrm{N}_{2} \mathrm{O}\right] / \mathrm{dt}$ is a change in the gas concentration within the chamber in the time interval $\left(\mathrm{L} \mathrm{min}^{-1}\right)$; $\mathrm{MW}$ is the molecular weight of the gas; $\mathrm{V}$ and $\mathrm{T}$ are the volume $(\mathrm{L})$ and the inner temperature $\left({ }^{\circ} \mathrm{K}\right)$ of the chamber; $\mathrm{P}$ is the pressure within the chamber, assumed as $1 \mathrm{~atm}$ and $\mathrm{R}$ is the universal gas constant (L atm K $\mathrm{mol}^{-1}$ ). The variation of the gas concentration over time was obtained by the angular coefficient of the adjusted linear regression. The daily mean $\mathrm{N}_{2} \mathrm{O}$ emission was calculated by the mean value of the three chambers installed in each treatment and the emission of the evaluation period was obtained by the integration of the area below the curve, which was established by the interpolation of the daily emission values.

\section{Soil analysis}

Simultaneously to air sampling, the soil temperature $(0.10 \mathrm{~m})$, gravimetric moisture, and the $\mathrm{NH}_{4}{ }^{+}$and the $\mathrm{NO}_{3}^{-}$contents $(0-0.10 \mathrm{~m})$ were monitored. The soil temperature was evaluated by geothermometers and soil moisture calculated by drying a sub-sample under forced air circulation at $105{ }^{\circ} \mathrm{C}$ for $24 \mathrm{~h}$. The soil $\mathrm{NH}_{4}{ }^{+}$and $\mathrm{NO}_{3}{ }^{-}$were extracted from the soil samples using $1.0 \mathrm{~mol} \mathrm{~L}^{-1} \mathrm{KCl}$ solution, determined by distillation in semi-micro Kjeldahl and acid titration (Tedesco et al., 1995). The microbial biomass activity was assessed based on the quantification of the soil $\mathrm{CO}_{2}$ - $\mathrm{C}$ flux (Baggs et al., 2003), determined by the concomitant $\mathrm{CO}_{2}$ and $\mathrm{N}_{2} \mathrm{O}$ analysis of the same air samples. In a GC 2014 chromatograph, $\mathrm{CO}_{2}$ was reduced to $\mathrm{CH}_{4}$ and quantified by a flame ionization detector (FID) at $250{ }^{\circ} \mathrm{C}$. WFPS was calculated based on the values of soil bulk density and gravimetric moisture.

\section{Statistical analysis}

The effect of the soil management systems on $\mathrm{N}_{2} \mathrm{O}$ emissions was evaluated by descriptive data analysis based on the mean standard deviation. Soil $\mathrm{N}_{2} \mathrm{O}$ emission, soil temperature, microbial biomass activity, WFPS, and the $\mathrm{NO}_{3}{ }^{-}$and $\mathrm{NH}_{4}{ }^{+}$soil contents were subjected to multivariate analysis based on Principal Coordinate Analysis (PCA), using software MULTIV (Pillar, 1997). The data of each variable were transformed by vectors (centering and normalization) and the product moment was used as similarity measure between the management systems on the different evaluation dates. Only coordinates with eigenvalues $>1$ and explaining $>30 \%$ of variability were considered. Coefficients of correlation $>0.60$ were included in the interpretation of the principal coordinates. The scatter diagram was complemented with cluster analysis, which allowed the verification of the similarity patterns among soil management systems in each field evaluation.

\section{RESULTS AND DISCUSSION}

\section{Meteorological conditions during the study period}

Mean daily air temperatures ranged from 4 to $18{ }^{\circ} \mathrm{C}$ during the study period, and rainfall from 0.1 to $69 \mathrm{~mm}$ (Figure 1). On average, the weather conditions were colder and wetter than in the normal mean. In May, the rainfall volume exceeded the normal average of the period by $24 \%(179 \mathrm{~mm})$, while the mean air temperature was $13 \%\left(14{ }^{\circ} \mathrm{C}\right)$ lower than the normal average in May.

\section{Soil $\mathrm{N}_{2} \mathrm{O}$ emission}

Soil $\mathrm{N}_{2} \mathrm{O}$ emissions were influenced by the tillage systems and the soybean and maize post-harvest residues (Figure 1). From the soybean crop residues, $\mathrm{N}_{2} \mathrm{O}$ emissions were higher in NT soil (164 $\mathrm{mg} \mathrm{m}^{-2}$ $\mathrm{N})$ than $\mathrm{CT}$ soil $\left(51 \mathrm{mg} \mathrm{m}^{-2} \mathrm{~N}\right)$. In the NT soil, the $\mathrm{N}_{2} \mathrm{O}$ emissions peaked in the first two evaluations, with a maximum of $670 \mathrm{mg} \mathrm{N} \mathrm{m}^{-2} \mathrm{~h}^{-1}$ recorded 19 days after soybean harvest. Afterwards, there was an exponential decrease of $\mathrm{N}_{2} \mathrm{O}$ emission, although in general slightly higher than the $\mathrm{N}_{2} \mathrm{O}$ emissions recorded in the $\mathrm{CT}$ soil (Figure 1 ), with a $\mathrm{N}_{2} \mathrm{O}$ peak $\left(143 \mathrm{~g} \mathrm{~m}^{-2} \mathrm{~h}^{-1} \mathrm{~N}\right)$ on the $29^{\text {th }}$ day after soybean harvest, which was more than four times lower than the respective value in NT soil (Figure 1). In an Oxisol, also in Rio Grande do Sul, Jantalia et al. (2008) found fluxes in the range of $80-150 \mathrm{mg} \mathrm{m}^{-2} \mathrm{~h}^{-1} \mathrm{~N}$ for both NT and CT in the first three weeks after sowing. The $\mathrm{N}_{2} \mathrm{O}$ emission ranges were therefore similar in the cited and the present study, although Jantalia et al. (2008) reported lower differences in soil $\mathrm{N}_{2} \mathrm{O}$ fluxes between tillage systems and a lower $\mathrm{N}$ peak emission compared to our results. On the whole-year basis, Jantalia et al. (2008) observed mean fluxes ranging from 8.1 to $18.7 \mathrm{mg} \mathrm{m}^{-2} \mathrm{~h}^{-1} \mathrm{~N}$. In a three-year study, Rochette et al. (2008) found that emissions from NT 

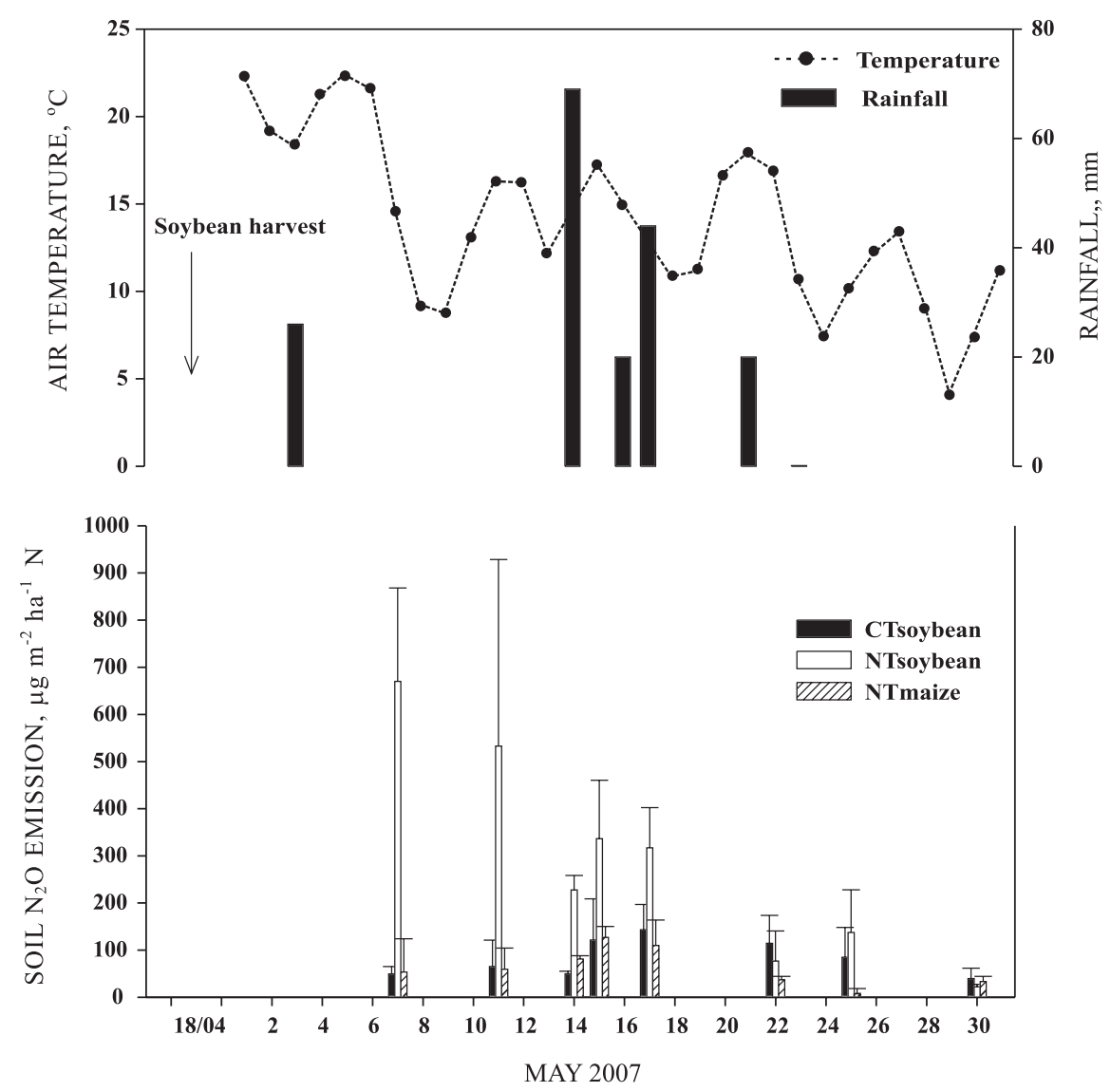

Figure 1. Rainfall, air temperature in May, and nitrous oxide $\left(\mathrm{N}_{2} \mathrm{O}\right)$ emission from a subtropical Oxisol in autumn (May 7 to 30, 2007), in Southern Brazil as influenced by tillage system (conventional CT and notillage NT) after soybean (CTsoybean and NTsoybean) and after maize harvest (NTmaize), in the rotation sequence black oat/soybean/black oat + common vetch/maize/radish oil/wheat/soybean. Bars represent the mean standard error.

plots in a poorly drained heavy clay soil were rarely different $(p>0.05)$ from those of moldboard plow plots when fluxes were low, but were greater during almost all episodes of high emissions, similarly to the trend observed here. In the study of Rochette et al. (2008), a few peaks of $\mathrm{N}_{2} \mathrm{O}$ fluxes in NT plots reached exceptionally high levels between 2.000 and $16.000 \mathrm{mg} \mathrm{m}^{-2} \mathrm{~h}^{-1} \mathrm{~N}$. The peaks of $\mathrm{N}_{2} \mathrm{O}$ fluxes from temperate, poorly drained soil (Gleysoil) were much higher than reported in our study with tropical, welldrained soil (Oxisol).

Other studies, in agreement with the present findings, also showed higher soil $\mathrm{N}_{2} \mathrm{O}$ emission from NT than from CT soils (Rice \& Smith, 1982; Smith et al., 2001; Yamulki \& Jarvis, 2002; Liu et al., 2006; Liu et al., 2007; Rochette et al., 2008; Gomes et al., 2009). The main reasons, according to those authors, is related to soil compaction and higher WFPS, resulting from the higher soil moisture, and in some cases, lower soil porosity in NT. These variables are inversely related to soil $\mathrm{O}_{2}$ diffusion, therefore favoring
$\mathrm{N}_{2} \mathrm{O}$ production by denitrifying bacteria activity. Nevertheless, in the soil investigated, the small difference in bulk density in the NT soil $\left(1.23 \mathrm{Mg} \mathrm{m}^{-3}\right.$ in the $0-0.10 \mathrm{~m}$ layer) in comparison to $\mathrm{CT}$ soil (1.20 $\mathrm{Mg} \mathrm{m}^{-3}$ at the same depth), and the considerable similarity of the WFPS values (Figure 2) cannot explain the 10 times higher $\mathrm{N}_{2} \mathrm{O}$ emissions from NT than from CT soil in the first sampling (Figure 1). This suggests the existence of other soil and crop management factors controlling $\mathrm{N}_{2} \mathrm{O}$ emission in NT soil, which will be approached by the multivariate analysis. At this same site, Chavez et al. (2009) and Pes (2009) found that the seeding operation in NT increased soil gas exchanges. These authors suggest that even the minimal soil disturbance by the driller was enough to increase GHG emission. In addition, Varner et al. (2003) reported that mortality of fine roots, due to their fast turnover, has the potential to contribute significantly to $\mathrm{N}_{2} \mathrm{O}$ production and fluxes. Keller et al. (2005) found that soil compaction also increased the $\mathrm{N}_{2} \mathrm{O}$ flux from a North Brazilian Oxisol. 


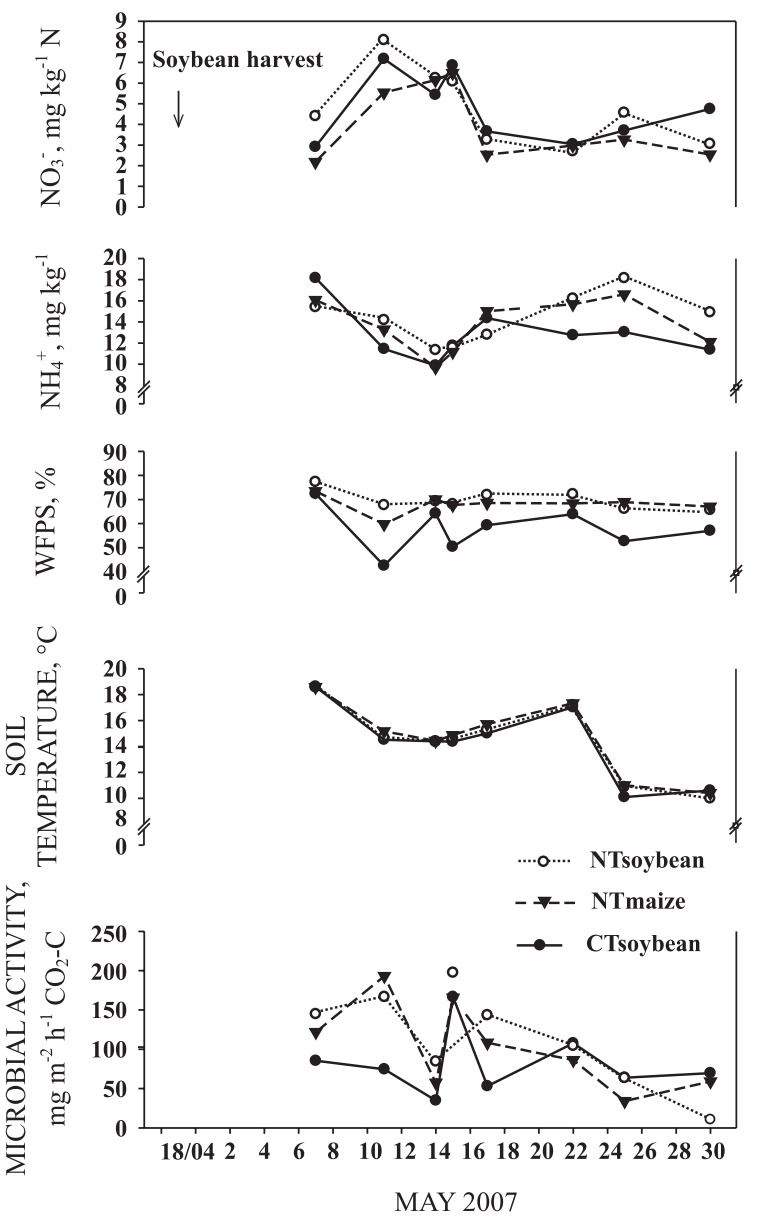

Figure 2. Microbial activity, contents of $\mathrm{NO}_{3}^{-}$and $\mathrm{NH}_{4}^{+}$, WFPS, and soil temperature of a subtropical Oxisol in autumn (May 7 to 30, 2007), in Southern Brazil as influenced by tillage systems (conventional tillage-CT and no-tillageNT) after soybean (CTsoybean and NTsoybean) and after maize harvest (NTmaize), in the rotation sequence black oat/soybean/black oat + common vetch/maize/radish oil/wheat/ soybean.

After maize harvest, the mean soil $\mathrm{N}_{2} \mathrm{O}$ emission in NT soil was $34 \mathrm{mg} \mathrm{m}^{-2} \mathrm{~N}$ in the evaluation period, with an $\mathrm{N}_{2} \mathrm{O}$ peak of $127 \mathrm{mg} \mathrm{m}^{-2} \mathrm{~h}^{-1} \mathrm{~N}$ (Figure 1), which was approximately five times below the maximum observed after soybean harvest. The lowest $\mathrm{N}_{2} \mathrm{O}$ soil emission in NT after maize harvest indicates, mainly, the microbial biomass assimilation of mineral $\mathrm{N}$ for high $\mathrm{C}: \mathrm{N}$ maize residue decomposition, mainly of $\mathrm{NO}_{3}^{-}$(Figure 2), decreasing the substrate to the $\mathrm{N}_{2} \mathrm{O}$ production by denitrification and nitrification processes in soil.

According to Aita \& Giacomini (2007), the decomposition of $\mathrm{N}$-rich crop residues, eg., of soybean, is less influenced by the lower soil-crop residue contact in NT soils than by a high $\mathrm{C}: \mathrm{N}$ ratio of the crop residues. This would explain the rapid increase in the soil mineral N contents observed under NT after soybean harvest (Figure 2). Consequently, the input of residues with a low $\mathrm{C}: \mathrm{N}$ ratio represents a high input of labile $\mathrm{C}$, which stimulated microbial activity and may have resulted in the considerable $\mathrm{O}_{2}$ consumption, creating anaerobic microsites in the soil surface layer and favoring $\mathrm{N}_{2} \mathrm{O}$ production in the NT soil (Smith et al., 2003). On the other hand, in CT soil this would have not occurred at the same intensity since plowing and harrowing tillage harmonized the crop residue distribution in the $0-0.20 \mathrm{~m}$ layer, disfavoring the formation of such microsites.

The positive correlation between $\mathrm{CO}_{2}$ and $\mathrm{N}_{2} \mathrm{O}$ fluxes ( $\mathrm{p}<0.007, \mathrm{n}=8, \mathrm{r}=0.52)$ supports this hypothesis, indicating that the highest soil $\mathrm{N}_{2} \mathrm{O}$ emission occurred simultaneously with the peak of soil microbial activity (Rice et al., 1988). In studies carried out in England and Germany, respectively, Baggs et al. (2003) and Sehy et al. (2003) also verified positive relations between the $\mathrm{CO}_{2}$ and $\mathrm{N}_{2} \mathrm{O}$ fluxes, emphasizing that mulch on the NT soil surface favored moisture conservation, besides gradually labile $\mathrm{C}$ input, essential in the denitrification process. The relation between labile $\mathrm{C}$ and the denitrifying activity in NT soil results in an increased $\mathrm{N}_{2} \mathrm{O}$ flux, as reported previously by Rice et al. (1988) and Liu et al. (2007).

The $\mathrm{N}_{2} \mathrm{O}$ emission peaks observed in this study were superior to those reported in earlier studies in a South Brazilian Alfisol (Gomes et al., 2009) and Oxisol (Jantalia et al., 2006; Metay et al., 2007; Jantalia et al., 2008), in which soil $\mathrm{N}_{2} \mathrm{O}$ emission rates were approximately five times lower than those found in this study. However, these studies were carried in spring-summer, and the first with maize was grown after common vetch (Vicia sativa L.), and the second and fourth during soybean growth. Therefore, in both experiments the growing plants absorbed available mineral soil $\mathrm{NO}_{3}{ }^{-}$and because it uncorroborated to $\mathrm{N}_{2} \mathrm{O}$ emission. This study conducted after soybean harvest possibly explains the higher soil $\mathrm{N}_{2} \mathrm{O}$ emission rates, since in this period, emission peaks of up to $3,500 \mathrm{mg} \mathrm{m}^{-2} \mathrm{~h}^{-1} \mathrm{~N}$ have been verified elsewhere (Yang \& Cai, 2005; Ciampitti et al., 2005; 2008), resulting from the large supply of labile organic $\mathrm{C}$ by the crop residues and from the exudates and products of nodule and root senescence, which are promptly metabolized by soil microorganisms (Rochette et al., 2004; Ciampitti et al., 2005; Yang \& Cai, 2005). In a Canadian heavy clay soil, Rochette et al. (2004) reported a short period of high emissions (up to $480 \mathrm{mg} \mathrm{m}^{-2} \mathrm{~h}^{-1} \mathrm{~N}$ ) after soybean harvest, presumably resulting from the high denitrification following the input of available $\mathrm{C}$ and $\mathrm{N}$ substrates when the soil water content was high. In central Iowa (USA), soybean fields exhibited $\mathrm{N}_{2} \mathrm{O}$ peak fluxes of $630 \mathrm{mg}$ $\mathrm{m}^{-2} \mathrm{~h}^{-1} \mathrm{~N}$, after rainfall events (Parkin \& Kaspar, 2006). These results are similar to those found in our study. 
Multivariate analysis of the main variables that control the soil $\mathrm{N}_{2} \mathrm{O}$ flux

The PCA analysis was used to identify the driving variables of $\mathrm{N}_{2} \mathrm{O}$ emissions. Through the ordination analysis of the values of $\mathrm{N}_{2} \mathrm{O}$ emissions and the soil variables, a scatter diagram was obtained for the three treatments (Figure 3). Axis 1 explained $36 \%$ of the data variability, and axis 2 explained $34 \%$ (Table 1). The variables with significant loading on axis 1 were $\mathrm{N}_{2} \mathrm{O}$ emission, microbial activity $\left(\mathrm{CO}_{2}-\mathrm{C}\right)$, soil temperature, and WFPS. On axis 2 , soil $\mathrm{NO}_{3}{ }^{-}$content had positive loading and soil $\mathrm{NH}_{4}{ }^{+}$content had a significant negative loading (Table 1 ).

The soil $\mathrm{N}_{2} \mathrm{O}$ emission of the group III ( $1^{\text {st }}, 2^{\text {nd }}$, $4^{\text {th }}$, and $5^{\text {th }}$ samplings in NT soybean postharvest and in the $4^{\text {th }}$ in NT maize postharvest) were the highest and were associated with soil temperature, microbial biomass activity, WFPS, and soil $\mathrm{NO}_{3}{ }^{-}$content (Figure 3). The relation of these variables with $\mathrm{N}_{2} \mathrm{O}$ flux in this group indicated $\mathrm{N}_{2} \mathrm{O}$ production by denitrification, which was favored by the high WFPS values (Smith et al., 2003; Liu et al., 2007) and the consumption of soil $\mathrm{O}_{2}$ due to the microbial activity oxidizing labile organic C (Figure 2) in NT soil, and consequent formation of anaerobic microsites. These results were similar to those reported by Khalil and Baggs (2005), who claimed that the denitrification process contributes considerably to agricultural soil
$\mathrm{N}_{2} \mathrm{O}$ emissions and that $\mathrm{NO}_{3}{ }^{-}$availability is the major driving variable regulating the magnitude of these emissions. On the other hand, in CT soil, the occurrence of anaerobic microsites is not probable even under soybean residues. In the other samplings (Groups I, II and IV), there was no prevailing control factor in the $\mathrm{N}_{2} \mathrm{O}$ emission, which may explain the lowest emission rates. In a previous study carried out in South Brazil, Jantalia et al. (2008) observed a poor relationship between WFPS and $\mathrm{N}_{2} \mathrm{O}$ flux. These authors associate this result to frequently low WFPS, of less than $40 \%$, despite heavy rain events (above $60 \mathrm{~mm}$ day) due to fast drainage into the Oxisol.

The findings of this study evidence the need of enhanced crop rotations under NT after legume grain crops, in particular soybean, to mitigate soil $\mathrm{N}_{2} \mathrm{O}$ emissions. For this purpose, the improvement of the synchronism between $\mathrm{N}$ release by the legume crop residues and the demand of the subsequent crop (graminea or crucifera) with high $\mathrm{N}$ demand may be a pormising strategy to reduce mineral $\mathrm{N}$ availability, and consequently, reduce $\mathrm{N}_{2} \mathrm{O}$ emissions. For the evaluation of the effect of soil management on reduction of soil $\mathrm{N}_{2} \mathrm{O}$ emissions in future research, the whole crop rotation cycle should idealistically be contemplated, taking the emission of the other GHGs into account as well as soil $\mathrm{C}$ accumulation and the $\mathrm{CO}_{2}$ - $\mathrm{C}$ costs of crop production systems.

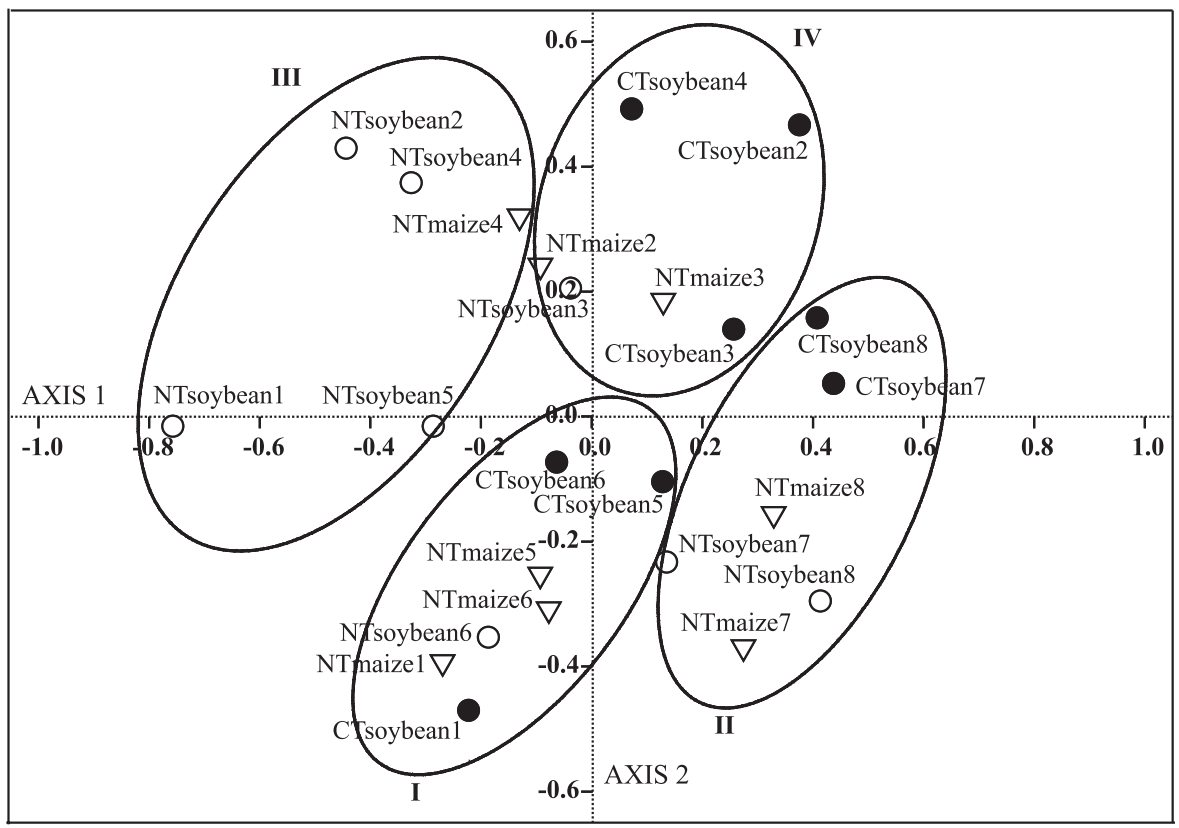

Figure 3. Scatter diagram of the variables and tillage systems (conventional-CT and no-tillage-NT) evaluated after soybean (CTsoybean and NTsoybean) and after maize harvest (NTmaize), in eight samplings (18), in the crop rotation black oat/soybean/black oat+common vetch/maize/radish oil/wheat/soybean under Rhodic Hapludox during autumn (May 7 to 30, 2007), in Southern Brazil. The clusters formed by the similarity between the management systems are indicated as I, II, III, and IV. 
Table 1. Correlation coefficients between the variables evaluated in a subtropical Oxisol in autumn (May 7 to 30, 2007), in Southern Brazil and the ordination axes obtained in the Principal Coordinate Analysis

\begin{tabular}{|c|c|c|}
\hline Variable & Principal & Coordinate \\
\hline & Axis 1 & Axis 2 \\
\hline Eigen values & 2.1 & 2.0 \\
\hline Percentage & 36 & 34 \\
\hline $\mathrm{N}_{2} \mathrm{O}$ emission $\left(\mu \mathrm{g} \mathrm{m}^{-2} \mathrm{~h}^{-1} \mathrm{~N}\right)$ & -0.75 & 0.34 \\
\hline Microbial activity $\left(\mathrm{mg} \mathrm{m}^{-2} \mathrm{~h}^{-1} \mathrm{C}\right)$ & -0.72 & 0.47 \\
\hline Soil temperature $\left({ }^{\circ} \mathrm{C}\right)$ & -0.77 & -0.13 \\
\hline WFPS (\%) & -0.63 & -0.53 \\
\hline $\mathrm{NH}_{4}^{+}\left(\mathrm{mg} \mathrm{kg}^{-1} \mathrm{~N}\right)$ & -0.27 & -0.76 \\
\hline $\mathrm{NO}_{3}^{-}\left(\mathrm{mg} \mathrm{kg}^{-1} \mathrm{~N}\right)$ & -0.06 & 0.91 \\
\hline
\end{tabular}

\section{CONCLUSIONS}

The $\mathrm{N}_{2} \mathrm{O}$ emission from soil after soybean harvest is higher under no-tillage than under conventional tillage. Results indicate that the denitrification process is the major source of $\mathrm{N}_{2} \mathrm{O}$ in the wet and cool autumn of Rio Grande do Sul, and that the main driving variables of $\mathrm{N}_{2} \mathrm{O}$ emissions are microbial biomass activity, soil temperature, water-filled pore space (WFPS), and soil $\mathrm{NO}_{3}{ }^{-}$content. The maximum soil $\mathrm{N}_{2} \mathrm{O}$ emissions found in this study after soybean harvest were higher than previously reported for Brazilian Oxisols. Nitrous oxide emissions can be reduced by the cultivation of maize in succession to soybean, and by the sowing of high-N-demanding winter cover crops immediately after soybean harvest.

\section{ACKNOWLEDGEMENTS}

The authors are indebted to the Fundação de Amparo a Pesquisa do Estado do Rio Grande do Sul (FAPERGS), Conselho Nacional de Desenvolvimento Científico e Tecnológico (CNPq), and the Ministério da Ciência e Tecnologia (MCT) for the financial support of the project PRONEX "Carbon sequestration and mitigation of greenhouse gas emissions by conservationist soil management systems and opportunities for agribusiness in Rio Grande do Sul, Brazil".

\section{LITERATURE CITED}

AITA, C. \& GIACOMINI, S.J. Matéria orgânica do solo, nitrogênio e enxofre nos diversos sistemas de exploração agrícola. In: YAMADA, T.; STIPP E ABDALLA, S.R. \& VITTI, G.C. Nitrogênio e enxofre na agricultura brasileira. Piracicaba, IPNI Brasil, 2007. p.1-41.
BAGGS, E.M.; STEVENSON, M.; PIHLATIE, M.; REGAR, A.; COOK, H. \& CADISCH, G. Nitrous oxide emissions following application of residues and fertiliser under zero and conventional tillage. Plant Soil, 254:361-370, 2003.

BAGGS, E.M.; CHEBII, J. \& NDUFA, J.K. A short-term investigation of trace gas emissions following tillage and no-tillage of agroforestry residues in Western Kenya. Soil Till. Res., 90:69-76, 2006.

CAMPOS, B.C. Dinâmica do carbono em Latossolo Vermelho sob sistemas de preparo de solo e de culturas. Santa Maria, Universidade Federal de Santa Maria, 2006. 188p. (Tese de Doutorado)

CERRI, C.C. \& CERRI, C.E.P. Seqüestro de carbono em solos na América Latina. B. Inf. SBCS, 32:40-44, 2007.

CIAMPITTI, I.A.; CIARLO, E.A. \& CONTI, M.E. Nitrous oxide emission during soybean culture: Inoculation and nitrogen fertilization effects. Ci Suelo, 23:123-131, 2005.

CIAMPITTI, I.A.; CIARLO, E.A. \& CONTI, M.E. Nitrous oxide emissions from soil during soybean [(Glycine $\max (\mathrm{L}$.) Merrill] crop phenological stages and stubbles decomposition period. Biol. Fert. Soils, 44:581-588, 2008.

CHAVEZ, L.F.; AMADO, T.J.C.; BAYER, C.; LA SCALA, N.; FIORIN, J.E.; CAMPOS, B.C. \& ESCOBAR, L.F. Carbon dioxide efflux in a Rhodic Hapludox as affected by tillage systems in Southern Brazil. R. Bras. Ci. Solo, 33:325-334, 2009.

DALAL, R.C.; WANG, W.; ROBERTSON, G.P. \& PARTON, W.J. Nitrous oxide emission from Australian agricultural lands and mitigation options: A review. Austr. J. Soil Res., 41:165-195, 2003.

EMPRESA BRASILEIRA DE PESQUISA AGROPECUÁRIA EMBRAPA. Centro Nacional de Pesquisa de Solos. Sistema brasileiro de classificação de solos. Rio de Janeiro, Embrapa-Solos, 2005. 374p.

EMPRESA BRASILEIRA DE PESQUISA AGROPECUÁRIA/ CENTRO NACIONAL DE PESQUISA DO MEIO AMBIENTE - EMBRAPA/CNPMA. Primeiro inventário brasileiro de emissões antrópicas de gases de efeito estufa: Emissões de óxido nitroso proveniente de solos agrícolas. Brasília, 2006. 105p.

FIRESTONE, M.K. \& DAVIDSON, E.A. Microbiological basis of $\mathrm{NO}$ and $\mathrm{N}_{2} \mathrm{O}$ production and consumption in soils. In: ANDREAE, M.O. \& SCHIMEL, D.S., eds. Exchange of trace gases between terrestrial ecosystems and the atmosphere. New York, Wiley, 1989. p.7-21.

GOMES, J.; BAYER, C.; COSTA, F.S.; PICCOLO, M.C.; ZANATTA, J.A.; VIEIRA, F.C.B. \& SIX, J. Soil $\mathrm{N}_{2} \mathrm{O}$ emissions under long term legume-based crop rotations in Southern Brazil. Soil Sci. Soc. Am. J., 2008.

INTERGOVERNMENTAL PANEL ON CLIMATE CHANGE IPCC. Climate change 2007: The physical science basis. The Fourth Assessment Report. Cambridge, UK, UNEP, 2007. 
JANTALIA, C.P.; ZOTARELLI, L.; SANTOS, H.P.; TORRES, E.; URQUIAGA, S.; BODDEY, R.M. \& ALVES, B.J.R. Em busca da mitigação da produção de óxido nitroso em sistemas agrícolas: Avaliação de práticas usadas na produção de grãos no Sul do País. In: ALVES, B.J.R.; URQUIAGA, S.; AITA, C.; BODDEY, R.M.; JANTALIA, C.P. \& CAMARGO, F.A.O., eds. Manejo de sistemas agrícolas. Impacto no seqüestro de $\mathrm{C}$ e nas emissões de gases de efeito estufa. Porto Alegre, Genesis, 2006. p.81107.

JANTALIA, C.P.; SANTOS, H.P.; URQUIAGA, S.; BODDEY, R.M. \& ALVES, B.J.R. Fluxes of nitrous oxide from soil under different crop rotations and tillage systems in the South of Brazil. Nutr. Cycl. Agroecosyst., 82:161-173, 2008.

KELLER, M.; VARNER, R.K.; DIAS, J.D.; SILVA, H.; CRILL, P.M.; OLIVEIRA, R.C. \& ASNER, G.P. Soil-atmosphere exchange of nitrous oxide, nitric oxide, methane, and carbon dioxide in logged and undisturbed forest in the Tapajos National Forest, Brazil. Earth Interact., 9:1-28, 2005.

KHALIL, M.I. \& BAGGS, E.M. $\mathrm{CH}_{4}$ oxidation and $\mathrm{N}_{2} \mathrm{O}$ emissions at varied soil water-filled pore spaces and headspace $\mathrm{CH}_{4}$ concentrations. Soil Biol. Biochem., 37:1785-1794, 2005

LEE, J.; SIX, J.; KING, A.P.; VAN KESSEL, C. \& ROLSTON, D.E. Tillage and field scale controls on greenhouse gas emissions. J. Environ. Qual., 35:714-725, 2006.

LIU, X.J.; MOSIER, A.R.; HALVORSON, A.D. \& ZHANG, F.S The impact of nitrogen placement and tillage on $\mathrm{NO}, \mathrm{N}_{2} \mathrm{O}$, $\mathrm{CH}_{4}$ and $\mathrm{CO}_{2}$ fluxes from a clay loam soil. Plant Soil, 280:177-188, 2006 .

LIU, X.J.; MOSIER, A.R.; HALVORSON, A.D.; REULE, C.A. \& ZHANG, F.S. Dinitrogen and $\mathrm{N}_{2} \mathrm{O}$ emissions in arable soils: Effect of tillage, $\mathrm{N}$ source and soil moisture. Soil Biol. Biochem., 39:2362-2370, 2007.

MALUF, J.R.T. Nova classificação climática do Estado do Rio Grande do Sul. R. Bras. Agrometerol., 8:141-150, 2000.

MAAG, M. \& VINTHER, F.P. Nitrous oxide emission by nitrification and denitrification in different soil types and at different soil moisture contents and temperatures. Applied Soil Ecol., 4:5-14, 1996.

METAY, A.; OLIVER, R.; SCOPEL, E.; DOUZET, J.M.; MOREIRA, J.A.A.; MARAUX, F.; FEIGL, B.J. \& FELLER, C. $\mathrm{N}_{2} \mathrm{O}$ and $\mathrm{CH}_{4}$ emissions from soils under conventional and no-till management practices in Goiânia (Cerrados, Brazil). Geoderma, 141:78-88, 2007.

MOREIRA, F.M.S. \& SIQUEIRA, J.O. Microbiologia e bioquímica do solo. 2.ed. Lavras, Universidade Federal de Lavras, 2006. 729p.

MORENO, J.A. Clima do Rio Grande do Sul. Porto Alegre, Secretaria da Agricultura, Secção de Geografia, 1961. 38p.

MOSIER, A.; SCHIMEL, D.; BRONSON, K. \& PARTON, W. Methane and nitrous oxide fluxes in native, fertilized and cultivated grassland. Nature, 350:330-332, 1991.
MOSIER, A.R.; DELGADO, J.A. \& KELLER, M. Methane and nitrous oxide fluxes in an acid Oxisol in western Puerto Rico: Effects of tillage, liming and fertilization. Soil Biol. Biochem., 30:2087-2098, 1998.

PARKIN, T.B. \& KASPAR, T.C. Nitrous oxide emissions from corn-soybean systems in the Midwest. J. Environ. Qual., 35:1496-1506, 2006.

PES, L.Z. Fluxo de gases de efeito estufa em sistemas de preparo do solo e rotação de culturas no Planalto do Rio Grande do Sul. Santa Maria, Universidade Federal de Santa Maria, 2009. 98p. (Tese de Mestrado)

PILLAR, V.D. Multivariate exploratory analysis and randomization testing with MULTIV. Coenoses, 12:145148, 1997.

RICE, C.W. \& SMITH, M.S. Denitrification in no-till and plowed soils. Soil Sci. Soc. Am. J., 46:1168-1173, 1982.

RICE, C.W.; SIERZEGA, P.E.; TIEDJE, J.M. \& JACOBS, L.W. Stimulated denitrification in the microenvironment of a biodegradable organic waste injected into soil. Soil Sci. Soc. Am. J., 52:102-108, 1988.

RIO GRANDE DO SUL. Secretaria da Agricultura e Abastecimento. Macrozoneamento agroecológico e econômico. Porto Alegre, SAA/EMBRAPA-CNPT, 1994. v. $2.57 \mathrm{p}$.

ROCHETTE, P.; ANGERS, D.A.; BÉLANGER, G.; CHANTIGNY, M.H.; PRÉVOST, D. \& LÉVESQUE, G. Emissions of $\mathrm{N}_{2} \mathrm{O}$ from alfalfa and soybean crops in Eastern Canada. Soil Sci. Soc. Am. J., 68:493-506, 2004.

ROCHETte, P.; ANGERS, D.A.; CHANTIGNY, M.H. \& BERTRAND, N. Nitrous oxide emissions respond differently to no-till in a loam and a heavy clay soil. Soil Sci. Soc. Am. J., 72:1363-1369, 2008.

SEHY, U.; RUSER, R. \& MUNCH, J.C. Nitrous oxide fluxes from maize fields: Relationship to yield, site-specific fertilization, and soil conditions. Agric. Ecosyst. Environ., 99:97-111, 2003.

SIX, J.; OGLE, F.J.; BREIDT, F.J.; CONANT, R.T.; MOSIER, A.R. \& PAUSTIAN, K. The potential to mitigate global warming with no-tillage management is only realized when practiced in long term. Global Change Biol., 10:155160, 2004.

SMITH, P.; GOULDING, K.W.; SMITH K.A.; POWLSON, D.S.; SMITH, J.U.; FALLOON, P. \& COLEMAN, K. Enhancing the carbon sink in European agricultural soils: Including trace gas fluxes in estimates of carbon mitigation potential. Nutr. Cycling Agroecosyst., 60:237-252, 2001.

SMITH, K.A.; BALL, T.; CONEN, F.; DOBBIE, K.E.; MASSHEDER, J. \& REY, A. Exchange of greenhouse gases between soil and atmosphere: Interactions of soil physical factors and biological processes. Europ. J. Soil Sci., 54:779-791, 2003.

TEDESCO, M.J.; GIANELLO, C.; BISSANI, C.A.; BOHNEN, H. \& VOLKWEISS, S.J. Analise de solo, plantas e outros materiais, 2.ed. Porto Alegre, Universidade Federal do Rio Grande do Sul, 1995. 174p. 
USDA - Soil Survey Staff. Soil Taxonomy - A basic system of soil classification for making and interpreting soil survey. 2.ed. Washington, 1999. 871p.

VARNER, R.K.; KELLER, M.; ROBERTSON, J.R.; DIAS, J.D.; SILVA, H.; CRILL, P.M.; McGRODDY, M. \& SILVER, W.L. Experimentally induced root mortality increased nitrous oxide emissions from tropical forest soils. Geophys. Res. Letters, 30:1144, 2003.

VINTEN, A.J.A.; BALL, B.C.; O'SULLIVAN, M.F. \& HENSHALL, J.K. The effects of cultivation method, fertilizer input and previous sward type on organic $\mathrm{C}$ and $\mathrm{N}$ storage and gaseous losses under spring and winter barley following long-term leys. J. Agric. Sci., 139:231243, 2002.
WEITZ, A.M.; LINDER, E.; FROLKING, S.; CRILL, P.M. \& KELLER, M. $\mathrm{N}_{2} \mathrm{O}$ emissions from humid tropical agricultural soils: Effects of soil moisture, texture and nitrogen availability. Soil Biol. Biochem., 33:1077-1093, 2001.

YAMULKI, S. \& JARVIS, S.C. Short-term effects of tillage and compaction on nitrous oxide, nitric oxide, nitrogen dioxide, methane and carbon dioxide fluxes from grassland. Biol. Fert. Soils, 36:224-231, 2002.

YANG, L. \& CAI, Z. The effect of growing soybean (Glycine $\max$ L.) on $\mathrm{N}_{2} \mathrm{O}$ emission from soil. Soil Biol. Biochem., 37:1205-1209, 2005. 